\title{
Pembangunan Perumahan Pada Areal Situs Biting, Lumajang
}

\section{Muhammad Hidayat}

Keywords: cultural resource management, conflict, development, conservation, regulation

\section{How to Cite:}

Hidayat, M. (1996). Pembangunan Perumahan Pada Areal Situs Biting, Lumajang. Berkala Arkeologi, 16(2), 62-72. https://doi.org/10.30883/jba.v16i2.754

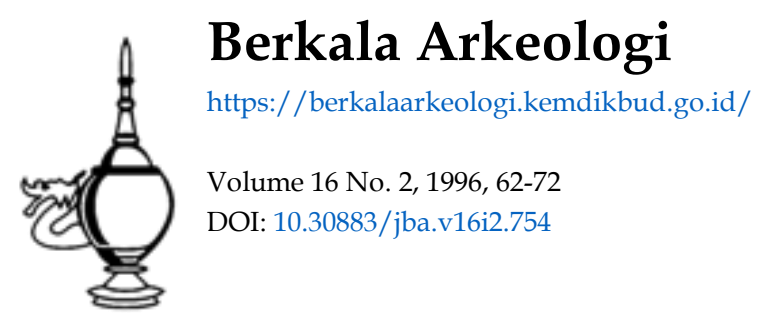

\section{(c) (1) (2)(2)}

This work is licensed under a Creative Commons Attribution-NonCommercial-ShareAlike 4.0 International License. 


\title{
PEMBANGUNAN PERUMAHAN \\ PADA AREAL SITUS BITING, LUMAJANG
}

\author{
Muhammad Hidayat \\ (Balai Arkeologi Yogyakarta)
}

\section{Pendahuiuan \\ 1.1. Situs Biting}

Situs Biting berada di dalam wilayah administrasi Desa Kutorenon, Kecamatan Sukodono, Kabupaten Lumajang. Bedasarkan penelitian yang dilakukan oleh Balai Arkeologi Yogyakarta, Situs Biting mencakup areal seluas 135 hektar. Situs tersebut dibatasi/dikelilingi oleh Sungai Ploso di sebelah barat, Sungai Bondoyudo di sebelah utara, Sungai Badung (Winong) di sebelah timur, dan Sungai Cangkring di sebelah selatan (Annonim, 1984).

Situs Biting berkaitan erat dengan tokoh legendaris masyarakat Lumajang dan sekitarnya, yaitu Menak Koncar, Berdasarkan sejarah, Menak Koncar dapat diidentikan dengan Nambi, salah satu pejabat tinggi Kerajaan Majapahit pada masa Raja R. Wijaya dan Jayanegara.

Keberadaan Situs Biting pertama kali diketahui bedasarkan hasil peninjauan yang dilakukan oleh J. Hageman pada tahun 1861. Kemudian pada tahun 1920, A Muhlenfeld melakukan peninjauan pula dan melanjutkan dengan penggalian percobaan (Anonim, 1984/85: 3).

Sejak tahun 1982 hingga tahun 1991, Balai Arkeologi Yogyakarta telah melakukan serangkaian penelitian terhadap situs tersebut. Hasil penelitian ini diketahui bahwa Situs Biting merupakan situs perbentengan (kota) dari abad XIV - XVII seluas 135 hektar. Sisa-sisa tembok/dinding keliling maupun bastion (pengungakan) benteng masih tampak, dan berada ditepi sepanjang Sungai Ploso, Bondoyudo, Badung, dan Cangkring. Ekskavasi yang telah dilakukan pada bagian dalam tembok keliling, telah ditemukan struktur- struktur bata yang diperkirakan merupakan fondasi bangunan. Ditemukan pula fragmen keramik Cina, tembikar, maupun logam yang merupakan sisa-sisa peralatan rumah tangga.

Pada tahun 1995, BAPPEDA Tingkat I Propinsi Jawa Timur bekerja sama dengan Balai Arkeologi Yogyakarta telah mengadakan studi kelayakan untuk pemanfaatan dan pengembangan Sumberdaya Budaya yang terdapat di wilayah Kabupaten Lumajang. Hasil studi tersebut telah merekomendasikan bahwa Situs Biting merupakan prioritas pertama untuk dimanfaatkan dan dikembangkan dalam kerangka pelestarian. Hal 
ini berdasarkan pada potensi yang terkandung pada situs tersebut, yaitu nilai kesejarahan, ilmu pengetahuan, kebudayaan, dan sosial-ekonomi. Adapun nilai penting yang terkandung pada situs Biting seperti berikut.

\section{Nilai Penting Kesejarahan}

Situs Biting tersebut merupakan bukti fisik perlawanan Nambi terhadap Jayanegara.

\section{Nilai Penting IImu Pengetahuan}

Sisa-sisa benteng mąsa klasik seperti Situs Biting sangat langka ditemukan di Indonesia, sehingga sangat penting untuk pengembangan itmu pengetahuan khususnya arkeologi dan sejarah arsitektur tradisiona!

\section{Nilai Penting Kebudayaan}

Tokoh Menak Koncar yang erat berkaitan dengan Situs Biting sampai saat ini masih erat berhubungan dengan masyarakat Lumajang. Legenda mengenai tokoh tersebut masih melekat di hati masyarakat Lumajang. sebagai tokoh dari masa lalu yang berkaitan dengan sejarah Lumajang

\section{Nilai Penting Sosial-ekonomi}

Sisa-sisa benteng, struktur bata dan sisa-sisa peralatan rumah tangga yang ditemukan di dalam benteng merupakan sarana peraga dalam pendidikan sejarah kebudayaan khususnya mengenai bentuk kota dan kehidupannya pada masa klasik. Peninggalan dari masa klasik yang langka dan berkaitan dengan tokoh legendaris Menak Koncar tersebut dapat pula menjadi daya tarik tersendiri untuk obyek wisata budaya. Selain itu benteng dan nama Menak Koncar yang sangat terkenal yang merupakan identitas dan akar sejarah masyarakat Lumajang ini dapat dijadikan sebagai citra kawasan (landmark) daerah Lumajang (Anonim, 1995).

Kegiatan pengelolaan Situs Biting hingga saat ini telah dilakukan oleh instansi yang berwenang, berupa penelitian dan pelestarian. Sesuai dengan wilayah kerjanya, instansi yang berwenang melakukan penelitian di Situs Biting adalah Balai Arkeologi Yogyakarta, sedang yang berwenang melakukan pelesatarian adalah Kantor Suaka Peninggalan Sejarah dan Purbakala (SPSP) Propinsi Jawa Timur.

Balai Arkeologi Yogyakarta telah melakukan sebelas kali penelitian terhadap Situs Biting yang ditujukan untuk mengetahui karakter situs, dan sekali melakukan penelitian untuk studi kelayakan yang bekerja sama dengan BAPPEDA Tingkat I Propinsi Jawa Timur. Sementara itu usaha 
pelestarian yang dilakukan oleh SPSP Propinsi Jawa Timur inventarisasi/registrasi, pemagaran kawat berduri pada salah satu pengungakan yang berada di paling utara, dan penempatan juru pelihara pada Makam Menak Koncar.

\section{Permasalahan}

Telah terjadi konflik dalam hal penataan dan pemanfaatan ruang yang menyangkut keberadaan Situs Biting. Akibat adanya konflik tersebut telah dan akan merugikan serta mengancam kelestarian Situs Biting. Situs Biting yang merupakan situs benteng/perkotaan masa klasik yang sangat penting di Indonesia yang mestinya sebagai Kawasan Lindung. sebagian arealnya akan diperuntukan bagi pembangunan perumahan oleh Perum PERUMNAS. Hal ini diketahui secara pasti berdasarkan surat dari Perum PERUMNAS Cabang VI, Nomor: Cab. VI/1913/05/96 tanggal 30 Mei 1996, yang dilampiri dengan Surat Rekomendasi Bupati Kepala Daerah Tingkat II Lumajang Nomor: 050/1055/434.51/1995 tanggal 22 Mei 1995, dan SuratKeputusan Kepala KantorPertanahan Kabupaten Lumajang Nomor: Kep/759/353.3 Tahun 1995 tentang Pemberian Ijin Lokasi untuk Keperluan Pembangunan Perumahan Rumah Sangat Sederhana dan Rumah Sederhana.

Surat dari Perum PERUMNAS Cabang V1 tersebut yang tembusannya ditujukan kepada Balai Arkeologi Yogyakarta diberitahukan bahwa pelaksanaan pembangunan Perumahan di Situs Biting akan dimulai pada bulan Juni 1996. Rencana tersebut telah mendapat ijin/ rekomendasi dari Bupati Kepala Daerah Tingkat II Lumajang dan Kantor Pertanahan Tingkat II Kabupaten Lumajang. Luas lahan yang dijinkan adalah sekitar 15 hektar, hingga tanggal 30 april 1996 telah dibebaskan/didapat lahan seluas 12,5 hektar. Lahan untuk perumahan tersebut berada di luar Situs Biting.

Surat rekomendasi yang dikeluarkan Bupati Kepala Daerah Tingkat II Lumajang yang dilampirkan pada surat dari Perum PERUMNAS, disebutkan bahwa ketentuan pembangunan perumahan harus memperhatikan keberadaan dan kelestarian Situs Biting. Selain itu diharapkan untuk berperan dalam mewujudkan pembangunan saranal prasarana yang menunjang kelestarian Situs Biting. Kawasan Situs Biting yang dimaksud adalah terletak di sepanjang sebelah utara searah ruas jalan Biting - Dawuhan Lor yang membujur dari timur ke barat

Sementara itu dalam surat ijin yang dikeluarkan Kantor Pertanahan Kabupaten Lumajang untuk pembangunan perumahan di Situs Biting. disebutkan bahwa rencana pembangunan perumahan telah sesuai 
dengan Rencana Detail Tata Ruang Kota L umajang dan Perda Tungkat It Lumajang No 08 Tahun 1993

\section{Tujuan dan Sasaran}

Terhadap permasalahan yang terjadi pada situs Biting tersebut Balai arkeologi Yogyakarta menindaklanjuti dengan mengadakan penelitian lapangan. Adapun penelitian ini dilakukan dengan tujuan untuk mengetahui penyebab konflik, serta mengetahui dampak yang diakibatkan adanya pembangunan Perumahan terhadap kelestarian situs Sementara sasaran yang hendak dicapai dalam penelitian ini adalah rekomendasi pelestarian situs. Rekomendasi tersebut diharapkan dapat dimanfaatkan sebagai bahan pertimbangan dalam penentuan kebijakan pelestarian Situs Biting, maupun sebagai acuan pada kasus-kasus sejenis di situs-situs lainnya

\section{Metode}

Alur penalaran yang digunakan dalam penelitian ini bersifat induktif, dengan tipe deskriptif. Pengumpulan data di lapangan dilakukan dengan pengamatan. Data yang dimaksudkan adalah lokasi rencana Perumahan. bentuk kegiatan konstruksi yang telah dilakukan, dan kerusakan situs yang telah muncul akibat adanya kegiatan konstruksi

Selain jenis dan bentuk dampak yang telah muncul tersebut, akan diprediksikan pula jenis, bentuk, dan besaran dampak lainnya akibat kegiatan konstruksi maupun pasca konstruksi. Untuk mendapatkan pemecahan dan jalan keluar dalam permasalahan ini digunakan pendekatan kebijakan penataan ruang dan pembangunan yang berwawasan lingkungan

\subsection{Hasil Pengamatan Lapangan}

Selama pengamatan lapangan di Situs Bitıng yang dilakukan pada tanggal 18 November 1996, telah didapatkan hal-hal sebagai berikut

4.1.1. Lahan seluas sekitar 15 hektar yang direncanakan untuk areal perumahan berada di areal Situs Biting, yaitu berada di dalam bekas benteng/kota

4.1.2. Pembangunan perumahan telah dimulai, dengan diawali permbuat an jalan yang membujur dari timur ke barat, dan pembuatan jembatan pada Sungai Ploso (Sungai Bondoyudo bagian atas)

4.1.3. Selama penggalian untuk pembuatan jalan, telah terangkat bata bata yang diperkirakan merupakan sisa-sisa bangunan kuna 
4.1.4. Pembuatan jembatan yang melintasi Sungaı Ploso diperkirakan tepat berada di atas tembok keliling benteng

\subsection{Konflik Pemanfaatan Ruang}

\subsubsection{Penyebab Konflik}

Pembangunan Perumahan di areal situs, seperti pada Situs Biting jelas telah menyimpang dari UU No. 24 Tahun 1992 Tentang Penataan Ruang. Seperti diketahui bahwa Situs Biting merupakan situs kepurbakalaan yang mestinya masuk dalam kawasan lindung. Dalam UU No 24 Tahun 1992 tersebut disebutkan bahwa salah satu tujuan penataan ruang adalah untuk terselenggaranya pengaturan pemanfaatan ruang kawasan lindung dan kawasan budidaya (Bab $V$ ). Penataan kawasan yang dimaksud di sini adalah penataan kawasan lindung dengan fungsi utama melindungi kelestarian lingkungan hidup yang mencakup sumberdaya alam dan sumberdaya buatan, diantaranya seperti Situs Biting.

Menilik pada Surat ljin atau Rekomendasi dari Bupati KDH Tingkat II Lumajang, bahwa telah terjadi kesalahan dalam pemahaman pengertian situs dan penentuan batas/luas situs sehingga ijin/rekomendasi pembangunan Perumahan di areal Situs Biting dikeluarkan. Sebenarnya Situs Biting tidak hanya pada areal yang masih tampak bangunan fisiknya (Makam Menak Koncar dan pengungakan) yang berada di sepanjang utara ruas jalan Biting - Dawuhan yang membujur dari Timur ke barat, namun situs tersebut pada areal seluas sekitar 135 hektar yang dikelilingi oleh aliran Sungai Bondoyudo, Ploso, Badung, dan Cangkring.

Sementara itu dalam Surat ljin pembangunan Perumahan yang dikeluarkan oleh Kantor Pertanahan Kabupaten Lumajang disebutkan bahwa rencana pembangunan Perumahan di Desa Kutorenon telah sesuai dengan Rencana Detail Tata Ruang Kota Lumajang dan Perda Tingkat II Lumajang No. 08 Tahun 1993. Hal ini menunjukkan bahwa dalam penyusunan Rencana Detail Tata Ruang Kota (pengaturan penataan dan pernanfaatan ruang) telah menyimpang dari UU No. 24 Tahun 1992, tidak memperhatikan keberadaan situs purbakala yang merupakan kawasan lindung. Penempatan ruang peruntukan pemukiman telah menempati (overlep) dengan ruang situs, dan kurang memperhatikan keberadaan situs tersebut (lihat peta)

Untuk merencanakan kegiatan yang berada di situs purbakala maupun peninggalan sejarah yang bernilai tinggi seperti di Situs Biting seharusnya/wajib dilengkapi dengan studi AMDAL Dalam Surat Keputusan Menteri Negara Lingkungan Hidup Ri No 11/MENLH/3/94 
tentang Jenis Usaha atau Kegiatan yang Wajib Dilengkapi dengan AMDAL, disebutkan bahwa untuk merencanakan kegiatan/usaha yang merubah fungsi atau peruntukan kawasan lindung, maupun merencanakan kegiatan pada areal yang berbatasan langsung dengan kawasan lindung harus dilengkapi dengan AMDAL. Mengenai pengelolaan Kawasan Lindung ini diantaranya telah diatur dalam UU No 24 Tahun 1992 tentang Penataan Ruang, dan Surat Keputusan Presiden RI No. 32 Tahun 1990 tentang Pengelolaan Kawasan Lindung. Dimaksud Kawasan Lindung di sini, diantaranya adalah lokasi situs purbakala atau peninggalan sejarah yang bernilai tinggi (Lampiran II Kep. Men. Neg. Lingkungan Hidup, No. KEP-11/MENLH/3/1994, tanggal 19 Maret 1994)

\subsubsection{Dampak Penting Terhadap Kelestarian Situs Biting}

Pembangunan perumahan di areal Situs Biting akan berdampak negatif terhadap kelestarian situs tersebut, baik pada tahap konstruksi maupun pasca konstruksi.

\subsubsection{Tahap Konstruksi}

Pada tahap konstruksi, kegiatan pembangunan perumahan khususnya pada pembuatan jembatan, jalan, maupun fondasi bangunan akan merubah maupun menghancurkan tinggaian arkeologis di dalamnya. Dampak ini telah tampak pada saat ini, yaitu terangkatnya bata-bata kuna (struktur bangunan kuna) pada saat penggalian untuk pembuatan jalan. Sementara itu bangunan-bangunan yang telah didirikan akan menutupi areal situs, sehingga akan merubah tampilan situs yang sebenarnya.

\subsubsection{Tahap Pasca Konstruksi}

Keberadaan bangunan perumahan akan mengundang pemukimanpemukiman baru dan kegiatan perekonomian lainnya (pertokoan, pasar, tempat hiburan) di sekitar kompleks perumahan. Keadaan ini akan memperluas pemanfaatan lahan situs untuk kegiatan- kegiatan tersebut, sehingga akan memperluas perusakan situs.

\section{Penutup}

Konflik pemantaatan ruang terjadi karena kurang dipahaminya karakter Situs Biting. Keberadaan situs tersebut masih belum diperhitungkan sebagai sumber daya pembangunan karena belum dimanfaatkan 


\subsection{Alternatif Pelestarian}

Pembangunan perumahan di Situs Biting telah dan akan terus berlangsung. Kerusakan situspun telah dan akan terus berlangsung. Ada dua alternatif untuk mencegah maupun mengurangi kerusakan Situs Biting, seperti berikut.

6.1.1. Membatalkan perijinan pembangunan di Situs Biting karena areal perumahan adalah benar-benar Kawasan Lindung. Pembatalan perijinan ini tentunya dilakukan oleh instansi yang mengeluarkan perijinan, dalam hal Pemda Kabupaten Lumajang (Bupati) dan Kantor Pertanahan Kabupaten Lumajang.

5.1.2. Pihak pemrakarsa/kontraktor Perum PERUMNAS harus meleng kapi/melakukan studi AMDAL karena areal perumahan merupakan Kawasan Lindung.

5.1.2.1. Mencegah perluasan pemanfaatan lahan situs untuk pemukiman dan pemanfaatan lainnya dari yang telah ditetapkan, yang merusak/mengancam kelestarian situs. Pencegahan ini dilakukan oleh Pemda setempat sebagai instansi yang berwenang, dengan mengeluarkan ketetapan pengaturan/penataan pemanfaatan ruang dan dilakukan pengawasan yang ketat.

5.1.2.2. Dilakukan pemintakatan (zoning) dengan sistem sel pada bagian-bagian situs yang penting dan diprioritaskan pada bagian yang terancam kelestariannya pada tahap konstruksi oleh pihak yang berwenang, dalam hal ini SPSP Prop. Jawa Timur. Kegiatan ini dapat dikoordinasikan dengan Pemda, Badan Pertanahan, Pemrakarsa, dan Kantor Depdikbud Kabupaten setempat.

5.1.2.3. Dilakukan penelitian penyelamatan data arkeologi (dengan penggalian) pada areal yang akan dibangun untuk Perumahan dan fasilitas umum lainnya. Kegiatan ini dilakukan oleh instansi yang berwenang, yaitu SPSP Prop. Jawa Timur dengan beaya dari Pemrakarsa pembangunan Perum PERUMNAS

5.1.2.4. Dilakukan pengawasan terhadap kegiatan pembangunan Perumahan dan merekam serta menyelamatkan data arkeologi yang ditemukan maupun terangkat Pengawasan ini dilakukan oleh 
SPSP Prop Jawa Timur dengan beaya dari Pemrakarsa pembangunan Perum PERUMNAS

Dua buah butir alternatif pelestarian tersebut dapat dipilih disesuaikan dengan kemungkinannya.

\subsection{Saran}

Kasus di Situs Biting dapat terjadi karena situs tersebut belum ditetapkan secara hukum sebagai Kawasan Cagar Budaya dan belum dikelola semestinya. Untuk menghindari kasus seperti di Situs Biting sudah saatnya situs-situs penting yang ada di Indonesia segera ditetapkan secara hukum sebagai Kawasan Cagar Budaya, dan dikelola pelestarian serta pernanfaatannya sesuai dengan potensinya

\section{Kepustakaan}

Abbas, Novida. 1992. Laporan Hasil Penelitian Arkeologi Situs Biting, Kelurahan Kutorenon, Kecamatan Sukodono, Kabupoaten Lumajang, Jawa Timur Tahap XI. Yogyakarta: Balai Arkeologi

Abbas, Novida dan Dewi, Enny Ratna. 1985. Penelitian Biting $V$, Lumajang, Jawa Timur, Laporan Penelitian Arkeologi, No. 7 Yogyakarta: Balai Arkeologi Yogyakarta.

Anonim. 1984/1985. Laporan Pertama Ekskavasi Biting IV, 1984 Yogyakarta: Balai Arkeologi Yogyakarta

Anonim.1987 Pedoman Pelaksanaan Peraturan Pemerintah Nomor: 29 Tahun 1986 tentang Analisis Dampak Lingkungan. Jakarta Sekretariat Menteri Negara Kependudukan \& Lingkungan Hidup

Anonim.1995. Studl Perencanaan Pengembangan Tempat-tempat Benda Bersejarah dan Purbakala di Kabupaten Lumajang. Provinsi Jawa Timur. BAPPEDA Tk. I Prop. Jawa Timur.

Badan Pengendalian Dampak Lingkungan. 1994 Keputusan Kepala Badan Pengendalian Dampak Lingkungan RI Nomor: Kep-056 Tahun 1994 tentang Pedoman Mengenai Ukuran Dampak Penting 
Departemen Pendidikan dan Kebudayaan RI. 1995 Undang-undang R! Nomor: 5 Tahun 1992 tentang Benda Cagar Budaya.

Kantor Menteri Negara Sekretaris Negara. 1991. Keputusan Presiden RI Nomor. 32 Tahun 1990 tentang Pengelolaan Kawasan Lindung

Kantor Badan Pertanahan Nasional Kabupaten Lumajang. 1995. Surat Keputusan Kepala Kantor Pertanahan Kabupaten Lumajang Nomor: Kep/759/353 3 Tahun 1995 tentang Pemberian IJIn Lokasi untuk Keperluan Pembangunan Perumahan Rumah Sangat Sederhana dan Rumah sederhana

Kantor Menteri Negara Kependudukan dan Lingkungan Hidup 1992 Undang-undang RI Nomor 24 Tahun 1992 tentang Penataan Ruang

1994. Keputusan Menteri Negara Lingkungan Hidup RI Nomor: Kep- 11/MENLH/3 1994 tentang Jenis Usaha atau Kegiatan yang Wajib Dilengkapi dengan Analisis Mengenai Dampak Lingkungan

1994. Keputusan Menteri Negara Lingkungan Hidup RI Nomor: Kep- 12/MENLH/3 1994 tentang Pedoman Umum Upaya Pengelolaan Lingkungan dan Upaya Pemantauan Lingkungan

1994. Keputusan Menteri Negara Lingkungan Hidup RI Nomor: Kep-13/MENLH/3 1994 tentang Pedoman Susunan Keanggotaan dan Tata Kerja Komisi AMDAL.

1994 Keputusan Menteri Negara Lingkungan Hidup RI Nomor Kep- 14/MENLH/3 1994 tentang Pedoman Umum Penyusunan Analisis Mengenai Dampak Lingkungan

Pemerintah Daerah TK II Kabupaten Lumajang 1995 Surat Rekomendasi Bupati Kepala Daerah Tingkat II Lumajang Nomor 050/1055/434 51/1995 tanggal 22 Mei 1995 


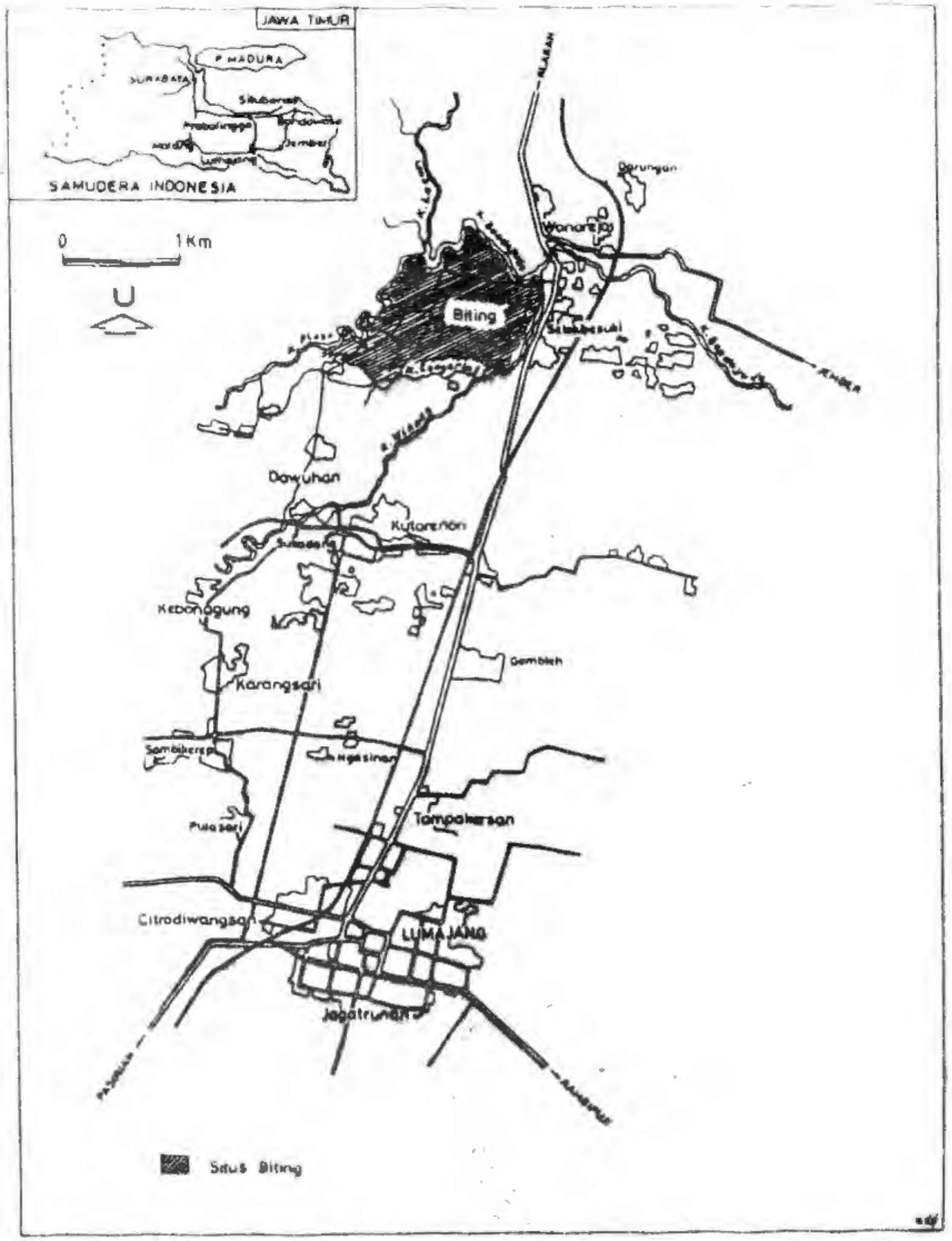

Cambar 1: Peta Keletakan Situs Biting

Desa Kutorenon, Kecamalan Sukodono, Lumiajang. 


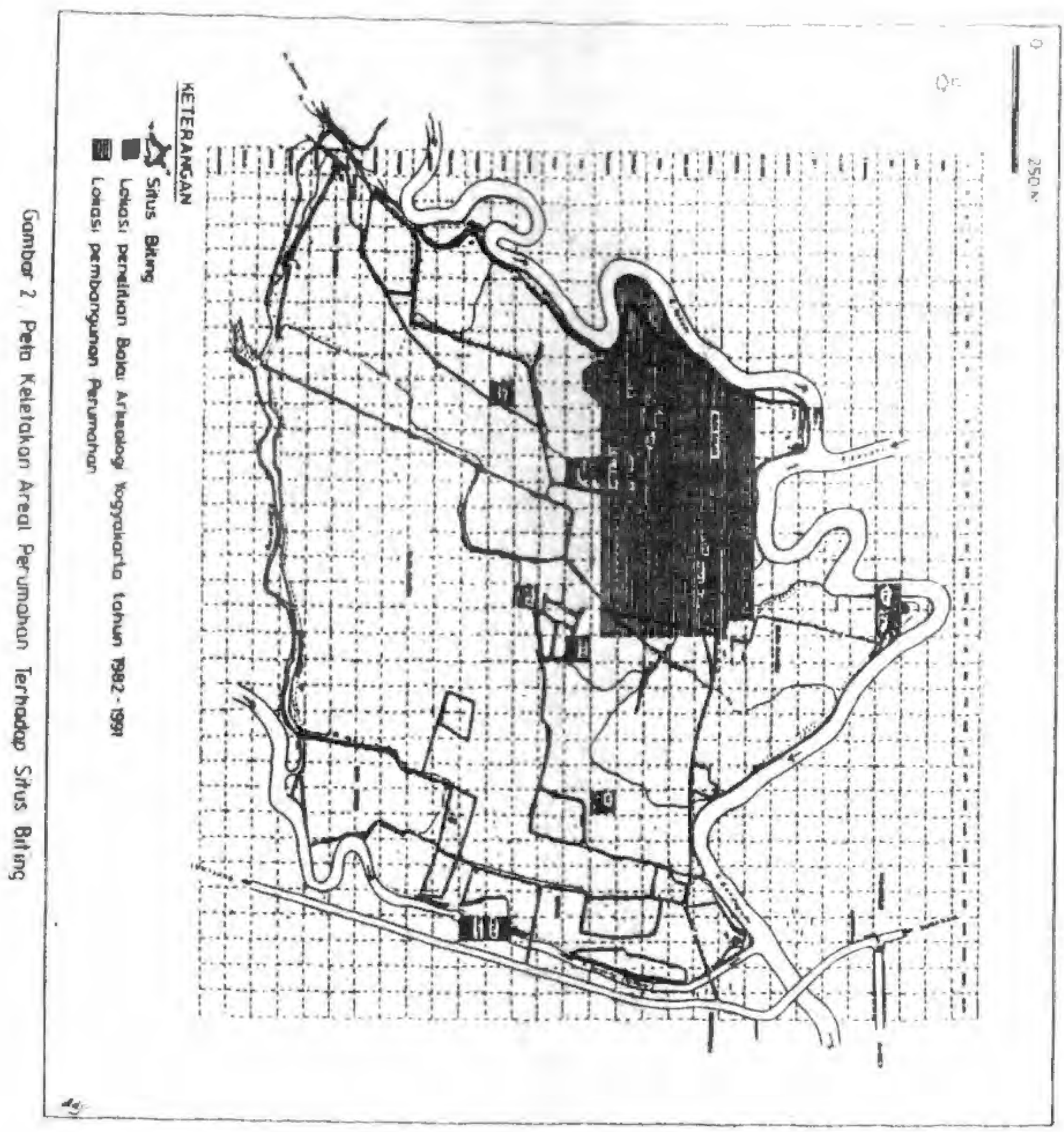

